\title{
Penerapan Teorema Bayes Untuk Diagnosis Penyakit Pada Ibu Hamil Berbasis Android
}

\author{
Nadya paramitha ${ }^{1}$, Erfian Junianto ${ }^{2}$, Sari Susanti ${ }^{3}$ \\ ${ }^{1}$ Universitas BSI \\ Email: nadyyprmth@gmail.com \\ ${ }^{2}$ Universitas BSI \\ Email: erfian.ejn@gmail.com \\ ${ }^{3}$ Universitas BSI \\ Email: sari.sra@bsi.ac.id
}

\begin{abstract}
Abstrak
Angka kematian ibu di Indonesia, sebagian besar disebabkan oleh kurangnya pengetahuan mengenai kehamilan, terlambatnya penanganan di rumah sakit, kurangnya tenaga medis maupun fasilitas yang memadai dan mahalnya biaya untuk konsultasi membuat para ibu enggan untuk ke dokter ahli. Sistem pakar diagnosa pada ibu hamil ini diharapkan dapat memberikan pengetahuan mengenai diagnosa penyakit gangguan kehamilan pada ibu hamil, memberikan sarana media konsultasi mengenai penyakit pada kehamilan serta mengurangi banyaknya biaya konsultasi ke dokter ahli. Sistem pakar adalah sistem yang mampu menggambarkan penalaran seorang pakar agar komputer dapat menyelesaikan masalah seperti yang biasa dilakukan oleh para ahli atau pakar. Teorema Bayes adalah cara untuk mengetahui probabilitas bersyarat. Probabilitas bersyarat adalah probabilitas dari suatu peristiwa yang terjadi, mengingat bahwa itu memiliki beberapa hubungan dengan satu atau lebih peristiwa lainnya. Aplikasi sistem pakar ini memakai Android sebagai sistem operasinya. Sistem operasi berbasis Android merupakan sistem operasi yang bersifat open source sehingga mudah dikembangkan dan dioptimalkan. Hasil dari penelitian ini yaitu aplikasi sistem pakar yang dapat memberikan pengetahuan mengenai diagnosa penyakit gangguan kehamilan, menjadi media untuk berkonsultasi mengenai penyakit pada masa kehamilan.
\end{abstract}

Kata Kunci: Kehamilan, Sistem Pakar, Teorema Bayes, Android

\begin{abstract}
The maternal mortality rate in Indonesia, mostly due to a lack of knowledge about pregnancy, late treatment at the hospital, lack of medical personnel and adequate facilities and the high cost of consultation make mothers reluctant to go to a specialist. An expert diagnostic system for pregnant women is expected to provide knowledge about diagnosing disorders of pregnancy disorders in pregnant women, providing media facilities for consultation about diseases in pregnancy and reducing the amount of consultation fees to expert doctors. Expert systems are systems that are able to describe the reasoning of an expert so that the computer can solve problems as is usually done by experts or experts. Bayes theorem is a way of knowing conditional probabilities. Conditional probability is the probability of an event occurring, given that it has several relationships with one or more other events. This expert system application uses Android as its operating system. Android-based operating system is an operating system that is open source so that it is easily developed and optimized. The results of this study are the application of an expert system that can provide knowledge about the diagnosis of pregnancy disorders, a media for consultation about diseases during pregnancy.
\end{abstract}

Key Word: Pregnancy, Expert System, Bayes Theorem, Android

\section{Pendahuluan}

Direktur Kesehatan Keluarga

Kementerian Kesehatan (Kemkes), Dr Eni Gustina MPH, mengatakan, angka kematian ibu di Indonesia karna melahirkan, kehamilan dan nifas terus meningkat. Pada tahun 2014 sebesar 4.525 kasus, tahun 2015 mencapai 4.890 kasus 
dan data yang diperoleh pada tahun 2016 telah mencapai 4.912 kasus (Handayani, 2017).

Kematian ibu karena melahirkan, kehamilan, dan nifas terjadi disaat mereka berada di lingkungan sekitar rumah maupun pada saat di perjalanan menuju rumah sakit. Dari angka kematian ibu di Indonesia, sebagian besar disebabkan oleh kurangnya pengetahuan mengenai kehamilan, terlambatnya penanganan di rumah sakit, kurangnya tenaga medis maupun fasilitas yang memadai dan mahalnya biaya untuk konsultasi membuat para ibu enggan untuk ke dokter ahli (Handayani, 2017). Karena itu maka dibutuhkan suatu alat bantu yang dapat memudahkan dalam mendiagnosa penyakit lebih dini agar dapat melakukan pencegahan lebih awal berupa sistem pakar.

Sistem pakar adalah sistem yang mampu menggambarkan penalaran seorang pakar agar komputer dapat menyelesaikan masalah seperti yang biasa dilakukan oleh para ahli atau pakar. Sistem pakar umumnya digunakan untuk konsultasi, analisis, diagnosis dan membantu mengambil keputusan (Rosnelly, 2012).

Penelitian mengenai sistem pakar penyakit pada ibu hamil sebelumnya pernah dilakukan dengan menggunakan metode forward chaining. Dalam penelitian tersebut, aplikasi sistem pakar dapat berfungsi untuk menghasilkan solusi penyakit sesuai dengan gejala-gejala yang diderita ibu hamil dan menjadi sarana untuk menyimpan pengetahuan tentang penyakit terutama yang berkenaan dengan jenis penyakit kehamilan dari para pakar atau ahlinya (Maryani \& Haryanto, 2018; Rahmayu, 2013; Ramanda, 2015). Selanjutnya sistem pakar penyakit pada ibu hamil menggunakan metode dempster shafer, dapat digunakan untuk membantu mendiagnosa penyakit kehamilan, Sistem dapat menampilkan hasil diagnosa berupa nama penyakit (Minardi \& Suyatno, 2016).

Dalam merancang sistem pakar ini menggunakan sebuah metode yaitu teorema bayes. Metode teorema bayes ini pernah digunakan untuk mendiagnosa penyakit mata pada manusia dengan presentasi keakuratan mencapai $80 \%$. Penggunaan metode teorema bayes dapat memberikan hasil akurat yang didapatkan dari perhitungan berdasarkan probabilitas gejala dan memberikan estimasi parameter dari hasil penyakitnya (Qamaruzzaman \& Sam'ani, 2016). Selanjutnya hasil penelitian yang mendiagnosa tentang penyakit tanaman kelapa sawit yang dapat membantu para petani dalam memberikan hasil diagnosa penyakit beserta solusi penanggulangannya (Sidauruk \& Pujianto, 2017).

Penggunaan teorema bayes juga pernah dilakukan pada seleksi fitur pada klasifikasi dokumen berita, diagnosa batu ginjal dan diagnosa penyakit anemia. Dengan menerapkan teorema bayes dalam sistem pakar tersebut dapat menghasilkan perhitungan valid sehingga proses prediksi dapat dilakukan dengan cepat dan akurat (Junianto \& Riana, 2017; Syahputra, Dahria, \& Putri, 2017).

Penulis menggunakan Android sebagai sistem operasinya. Sistem operasi berbasis Android merupakan sistem operasi yang bersifat open source sehingga mudah dikembangkan dan dioptimalkan. Selain itu, sistem operasi Android bersifat fleksibel karena mampu disematkan pada hardware dengan spesifikasi tinggi maupun rendah (Dini, 2016).

Berdasarkan dari uraian tersebut, maka penulis tertarik untuk membuat suatu aplikasi sistem pakar menggunakan metode teorema bayes sebagai layanan kesehatan pada ibu hamil dengan judul "Penerapan Teorema Bayes untuk Diagnosa Penyakit pada lbu Hamil Berbasis Android."

\section{Metode Penelitian}

Metode penelitian yang digunakan penulis dalam pembuatan aplikasi ini adalah metode pengumpulan data dan metode pengembangan pakar. Hal ini dilakukan agar dalam tahap pengerjaan berjalan dengan baik dan sesuai prosedur.

\section{Metode Pengumpulan Data}

Teknik pengumpulan data merupakan langkah yang paling strategis dalam penelitian, karena tujuan utama dari penelitian adalah mendapatkan data (Sugiyono, 2008). Teknik pengumpulan data yang penulis lakukan adalah :
1. Observasi
Penulis melakukan pengamatan
langsung dengan mendatangi lokasi kediaman dokter (pakar).
2. Wawancara 
Dalam penulisan skripsi ini, untuk mendapatkan informasi data yang lengkap dan akurat maka penulis melakukan wawancara langsung dengan dokter (pakar) melalui tanya jawab dengan dokter (pakar) di bidang kandungan.

3. Studi Pustaka

Studi pustaka merupakan metode pengumpulan data dengan cara pengumpulan informasi dari artikel, buku, literatur atau tulisan pada situs internet atau media lainnya. Studi pustaka yang peneliti lakukan ditujukan untuk mengetahui secara rinci mengenai gejala ganguan kehamilan, macammacam gangguan kehamilan dan pemrograman Android.

\section{Metode Pengembangan Pakar}

Teorema Bayes adalah cara untuk mengetahui probabilitas bersyarat. Probabilitas bersyarat adalah probabilitas dari suatu peristiwa yang terjadi, mengingat bahwa itu memiliki beberapa hubungan dengan satu atau lebih peristiwa lainnya.

Teorema Bayes memiliki bentuk umum sebagai berikut (Kusrini \& Luthfi, 2009):

$$
P(H \mid X)=\frac{P(X \mid H) P(H)}{P(X)}
$$

Dalam hal ini:

$$
\begin{aligned}
& \mathrm{X}=\text { data dengan class yang belum } \\
& \text { diketahui } \\
& \mathrm{H}=\text { hipotesis data } \mathrm{X} \text { merupakan } \\
& \text { suatu } \\
& \text { class spesifik } \\
& \mathrm{P}(\mathrm{HIX})=\text { probabilitas hipotesis } \mathrm{H} \text { berdasar } \\
& \text { kondisi } X \\
& \mathrm{P}(\mathrm{H}) \quad=\text { probabilitas hipotesis } \mathrm{H} \\
& \mathrm{P}(\mathrm{X} \mid \mathrm{H})=\text { Probabilitas } \mathrm{X} \text { berdasarkan } \\
& \text { kondisi pada hipotesis } \mathrm{H} \\
& \mathrm{P}(\mathrm{X}) \quad=\text { Probabilitas dari } \mathrm{X}
\end{aligned}
$$

\section{Algoritma Sistem Pakar}

Algoritma yang akan diimplementasikan pada program sistem pakar ini yaitu di mulai dari proses tampilkan pilihan gejala dan pilih gejala kemudian input dengan memilih gejala kemudian tampil suatu kemungkinan yang akan menghasilkan beberapa kemungkinan jawaban atau pilihan dan diakhiri dengan hasil diagnosa berikut dengan prosentasenya. Untuk keterangan lebih jelas bisa dilihat pada Gambar 1.

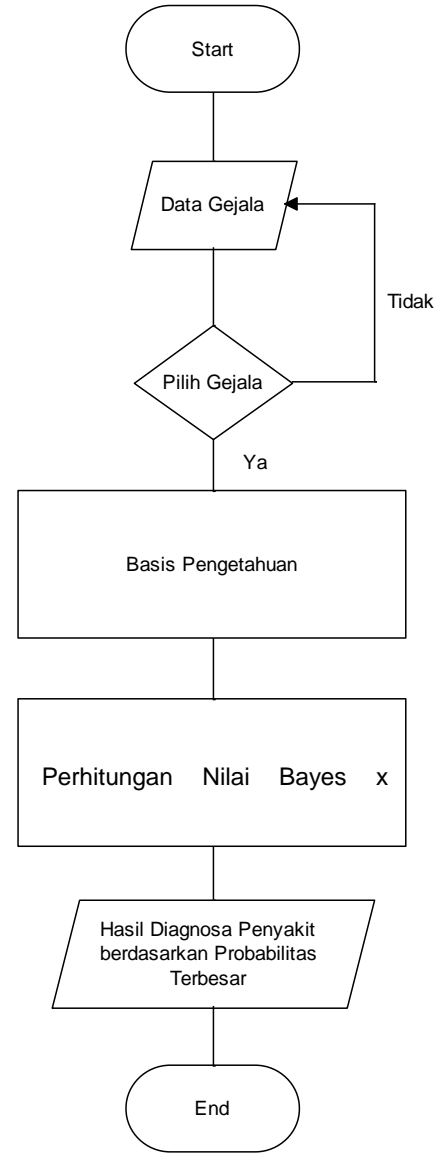

Gambar 1. Algoritma Sistem Pakar

\section{Hasil dan Pembahasan Tabel Pakar}

Dalam membangun sebuah aplikasi sistem pakar diagnosis penyakit pada ibu hamil, penulis menentukan beberapa tabel yang dibutuhkan aplikasi adapun tabel yang penulis buat, diantaranya :

Tabel 1. Daftar Penyakit

\begin{tabular}{ll} 
Kode & \multicolumn{1}{c}{ Nama Penyakit } \\
\hline P001 & Hamil Anggur (Molahidatidosa) \\
\hline P002 & Premature Rupture of Membranes (PROM) \\
\hline P003 & Plasenta Previa \\
\hline P004 & Solusio Plasenta \\
\hline P005 & Infeksi Saluran Kemih \\
\hline P006 & Pre-Eklampsia \\
\hline P007 & Anemia Kehamilan \\
\hline P008 & Blighted Ovum \\
\hline P009 & Gestional Diabetes \\
\hline P010 & Kehamilan Ektopik \\
\hline P011 & Polihidramnion \\
\hline P012 & Hiperemesis gravidarum (HG) \\
\hline P013 & Eklampsia \\
\hline P014 & Abortus Inkomplit \\
\hline P015 & Abortus Imminens \\
\hline
\end{tabular}

Tabel 2. Daftar Gejala 


\begin{tabular}{ll} 
Kode & \multicolumn{1}{c}{ Nama Gejala } \\
\hline G001 & Mual \\
\hline G002 & Mual dan Muntah \\
\hline G003 & $\begin{array}{l}\text { Pendarahan atau Flek } \\
\text { Berwarna Coklat dan Bergelembung }\end{array}$ \\
\hline G004 & Pendarahan ringan melalui Vagina \\
\hline G005 & Pendarahan tanpa rasa nyeri \\
\hline G006 & Pendarahan berulang kali \\
\hline G007 & Nyeri pada tulang panggul \\
\hline G008 & Nyeri pada tubuh bagian bawah \\
\hline G009 & Nyeri pada pundak leher dan rektum \\
\hline G010 & Nyeri ringan pada Abdomen \\
\hline G011 & Gelisah \\
\hline G012 & Pusing dan Lemas \\
\hline G013 & Bengkak pada Wajah atau Tangan \\
\hline G014 & Gangguan Penglihatan \\
\hline G015 & Gangguan saat buang air kecil \\
\hline G016 & Berat Badan naik Mendadak \\
\hline G017 & Berat Badan menurun Mendadak \\
\hline G018 & Buang Air kecil Sedikit \\
\hline G019 & Lebih sering buang air kecil \\
\hline G020 & $\begin{array}{l}\text { Rasa tidak nyaman atau perih saat } \\
\text { Buang air kecil atau berhubungan }\end{array}$ \\
\hline G021 & Cepat Lelah
\end{tabular}

Tabel keputusan pakar dibuat untuk menghubungkan tabel kerusakan

\begin{tabular}{ll} 
G022 & Pucat \\
\hline G023 & Sesak Napas \\
\hline G024 & Susah Konsentrasi \\
G025 & $\begin{array}{l}\text { Keluar cairan yang } \\
\text { berbau khas }\end{array}$ \\
\hline G026 & $\begin{array}{l}\text { Keluarnya cairan } \\
\text { yang tertahankan }\end{array}$ \\
\hline G027 & Sakit perut tiba-tiba dan terus menerus \\
\hline G028 & Perut terasa Tegang / Kram \\
\hline G029 & Rasa Sakit perut bagian atas \\
\hline G030 & Ukuran Perut membesar \\
\hline G031 & Denyut Jantung Janin susah dilacak \\
\hline G032 & Pemeriksaan Denyut janin Normal \\
\hline G033 & Terjadi di Tri-Semester Akhir \\
\hline G034 & Vagina Berbintik atau berdarah \\
\hline G035 & Menstruasi lebih berat dari biasanya \\
\hline G036 & Peningkatan tekanan darah hingga (140/90) \\
\hline G037 & Adanya protein dalam Air Seni \\
\hline G038 & Persalinan Lebih Cepat \\
\hline G039 & Pembesaran Uterus sesuai Masa Kehamilan \\
\hline G040 & Serviks masih Membuka \\
\hline G041 & Serviks Tertutup \\
\hline G042 & Nyeri yang sangat hebat \\
\hline
\end{tabular}

dengan tabel gejala, keterangan dapat dilihat di Tabel 3.

Tabel 3. Tabel Keputusan Pakar

\begin{tabular}{|l|l|l|l|l|l|l|l|l|l|l|l|l|l|l|l|}
\hline Kode & P01 & P02 & P03 & P04 & P05 & P06 & P07 & P08 & P09 & P010 & P011 & P012 & P013 & P014 & P015 \\
\hline G001 & & & & & & & X & & X & & & X & & & \\
\hline G002 & X & & & X & & & & & & X & & & X & & \\
\hline G003 & X & & & & & & & & & & & & & & \\
\hline G004 & & & & X & & & & & & X & & & & & X \\
\hline G005 & & & X & & & & & & & & & & & & \\
\hline G006 & & & X & & & & & & & & & & & X & \\
\hline G007 & X & & & & & & & & & & & & & & \\
\hline G008 & & & & & X & & & & & X & & & & & \\
\hline G009 & & & & & & & & & & X & & & & & \\
\hline G010 & & & & & & & & & & & & & & & X \\
\hline G011 & X & & & & & & & & & & & X & & & \\
\hline G012 & & & & X & & X & X & & & X & & X & X & & \\
\hline G013 & & & & & & X & & & & & & & X & & \\
\hline G014 & & & & X & & X & & & X & & & & X & & \\
\hline G015 & & & & & & & & & & & & & X & & \\
\hline G016 & & & & & & & & & & & & & X & & \\
\hline G017 & & & & & & & & & & & & X & & & \\
\hline G018 & & & & & X & & & & & & X & X & & & \\
\hline G019 & & & & & X & & & & X & & & & & & \\
\hline G020 & & & & & X & & & & & & & & & & \\
\hline G021 & & & & & & & & X & & & & & & \\
\hline G022 & & & & & & & X & & & & & & & & \\
\hline G023 & & & & & & & X & & & & X & & & & \\
\hline G024 & & & & & & & X & & & & & & & & \\
\hline G025 & & X & & & & & & & & & & & & \\
\hline
\end{tabular}




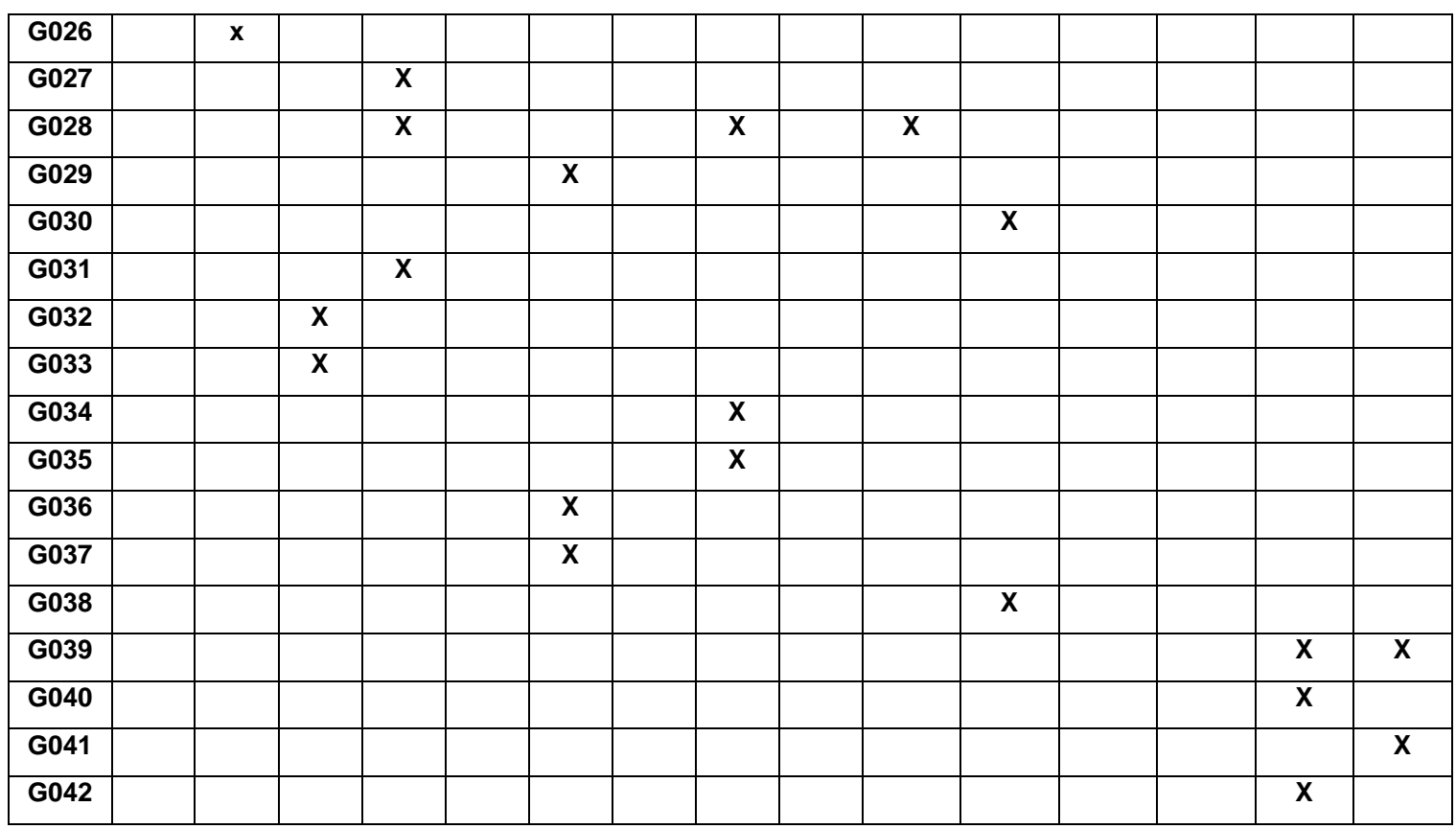

Dalam sistem pakar menentukan jenis penyakit pada ibu hamil ini terdapat perhitungan menggunakan Teorema Bayes.

Nilai probabilitas penyakit didapatkan dari 1 / Banyaknya jumlah penyakit yang ada. Sedangkan probabilitas gejala didapatkan dari 1 / jumlah gejala tertentu yang ada diseluruh penyakit.

Misalkan dalam menentukan penyakit, ibu hamil memilih beberapa gejala diantaranya:

1. Perut terasa Tegang / Kram (G028)

2. Vagina Berbintik atau berdarah (G034)

3. Menstruasi Lebih berat dari biasanya (G035) .

Berikut contoh perhitungan Teorema

Bayes:

Menghitung total bayes pada Probabilitas

Penyakit pada Solusio Plasenta P004

1. $P(P 004 \mid G 028)$

$=$

$(1 * 0,067)+\left(1^{*} 0,067\right)+(1 * 0,067)$

$=0.333$

2. $\mathrm{P}(\mathrm{P} 004$ | G034)

$=\underline{(0 * 0,067)}$

$(1 * 0,067)$

$=0$

3. $P(P 004 \mid G 035)$

$=\underline{(0 * 0,067)}$

$(1 * 0,067)$
$=0$

Total Bayes $1(\mathrm{P} 004)=0.333+0+0=$ 0.333

Menghitung total bayes pada Probabilitas Penyakit pada Blighted Ovum P008

1. $P(P 008 \mid G 028)$

$=\frac{\left(1^{*} 0,067\right)}{\left(1^{*} 0,067\right)+\left(1^{*} 0,067\right)+\left(1^{*} 0,067\right)}$

$=0.333$

2. $P(P 008 \mid G 034)$

$=(1 * 0,067)$

$(1 * 0,067)$

$=1$

3. $P(P 008 \mid G 035)$

$=\underline{(1 * 0,067)}$

$(1 * 0,067)$

$=1$

Total Bayes $2(\mathrm{P} 008)=0.333+1+1=$ 2.333

Menghitung total bayes pada Probabilitas Penyakit pada Kehamilan Ektopik P010 1. $\mathrm{P}(\mathrm{P} 010 \mid \mathrm{G} 028)$

$$
\begin{aligned}
& =\frac{(1 * 0,067)}{(1 * 0,067)+(1 * 0,067)+(1 * 0,067)} \\
& =0.333
\end{aligned}
$$


2. $P(P 010 \mid G 034)$

$=\underline{(0 * 0,067)}$

$(0 * 0,067)$

$=0$

3. $P(P 010 \mid G 035)$

$=\underline{(0 * 0,067)}$

$(0 * 0,067)$

$=0$

Total Bayes $3(\mathrm{P} 010)=0.333+0+0=$ 0.333

Hasil Akhir Bayes $=$ Bayes $1+$ Bayes $2+$ Bayes 3

Hasil Akhir Bayes $=0.333+2.333+0.333$

Hasil Akhir Bayes $=2.999$

$$
\begin{aligned}
P(P 004) & =\frac{0,333}{2,999} \times 100 \% \\
& =0.11 \times 100 \%=11 \%
\end{aligned}
$$

$P(P 008)=\frac{2,333}{2,999} \times 100 \%$

$$
=0.77 \times 100 \%=77 \%
$$

$P(P 004)=\frac{0,333}{2,999} \times 100 \%$

$$
=0.11 \times 100 \%=11 \%
$$

Dari hasil diatas nilai penyakit tertinggi adalah hasil diagnosa penyakit yang sedang dialami ibu hamil yaitu, Blighted Ovum atau P008 dengan prosentase $77 \%$.

\section{Analisa Kebutuhan Software}

Di dalam analisa kebutuhan software ini akan dijelaskan tahapan perancangan sistem yang akan dibuat untuk mempersiapkan proses implementasi sistem dan untuk menggambarkan secara jelas proses-proses yang diinginkan di dalam membangun perangkat lunak.

\section{Use Case Diagram}

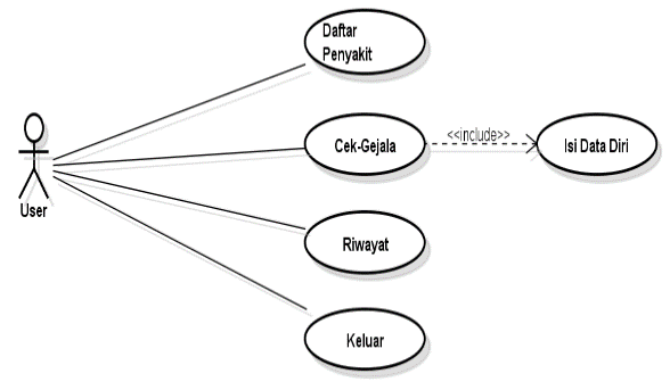

Gambar 2. Use Case Diagram
2. Activity Diagram Halaman Daftar Penyakit

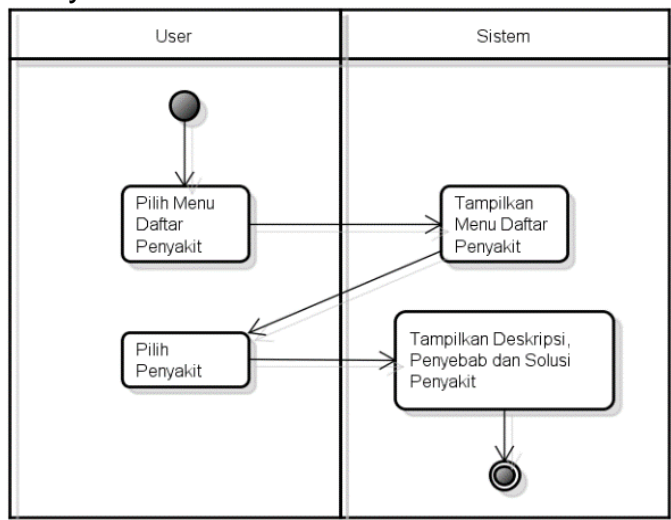

Gambar 3. Activity Diagram Halaman Daftar Penyakit

3. Activity Diagram Halaman Isi Data Diri

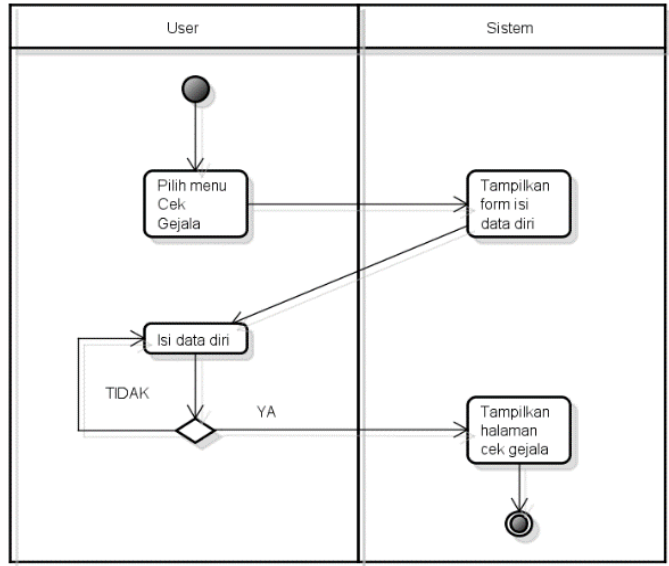

Gambar 4. Activity Diagram Halaman Isi Data Diri

4. Activity Diagram Halaman Konsultasi Cek Gejala

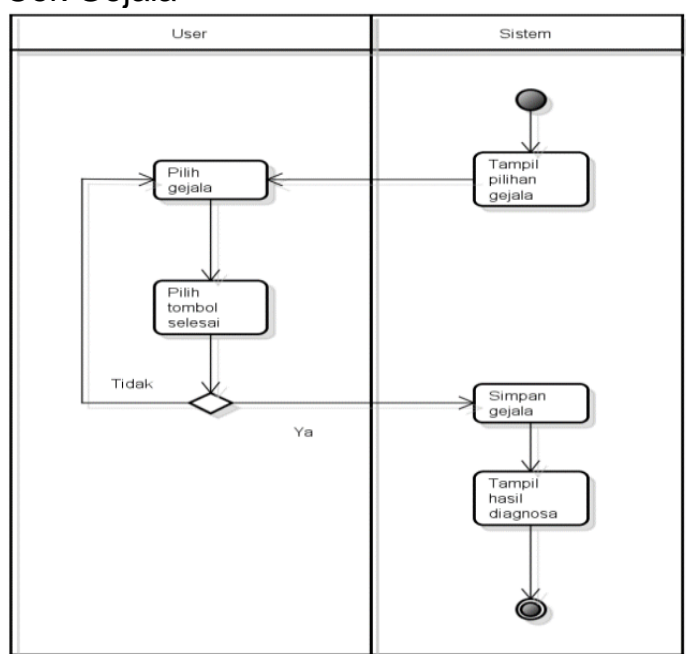

Gambar 5. Activity Diagram Halaman Konsultasi Cek Gejala 
5. Activity Diagram Halaman Lihat Riwayat

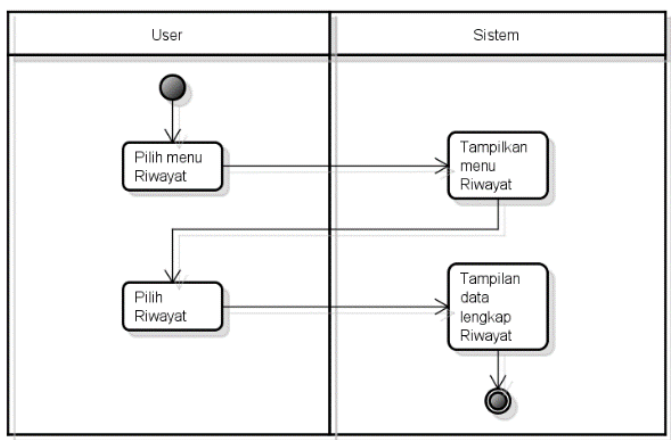

Gambar 6. Activity Diagram Halaman Liat Riwayat

\section{User Interface}

Berikut merupakan tampilan antarmuka dari sistem pakar diagnosa penyakit pada ibu hamil dari tampilan antarmuka untuk pengguna

1. Splash Screen

Tampilan splash screen merupakan halaman pembuka pada saat pertama kali mengakses aplikasi sistem pakar diagnosa penyakit pada ibu hamil.

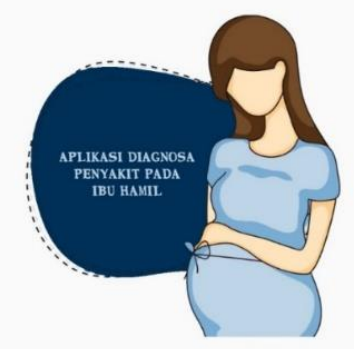

Gambar 7. Screenshot Splash Screen

\section{Halaman Beranda}

Tampilan halaman beranda merupakan halaman awal pada saat pertama kali mengakses aplikasi sistem pakar diagnosa penyakit pada ibu hamil. Berisikan halaman-halaman tentang daftar informasi penyakit, halaman cek gejala, halaman tentang dan menu keluar.
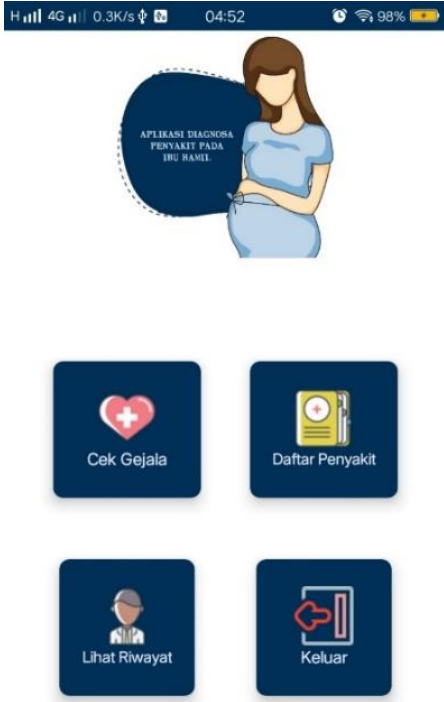

Gambar 8. Screenshot Halaman Beranda

3. Halaman isi data diri

Tampilan halaman isi data diri merupakan halaman yang berisikan tentang user mengisi data diri untuk selanjutnya melakukan cek gejala.

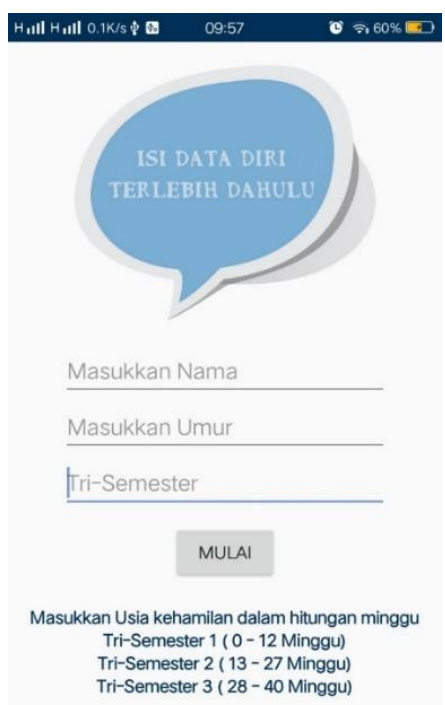

Gambar 9. Screenshot Halaman Isi Data Diri

4. Halaman Daftar Penyakit

Tampilan halaman daftar penyakit merupakan halaman yang berisikan halaman tentang daftar penyakit pada ibu hamil. 


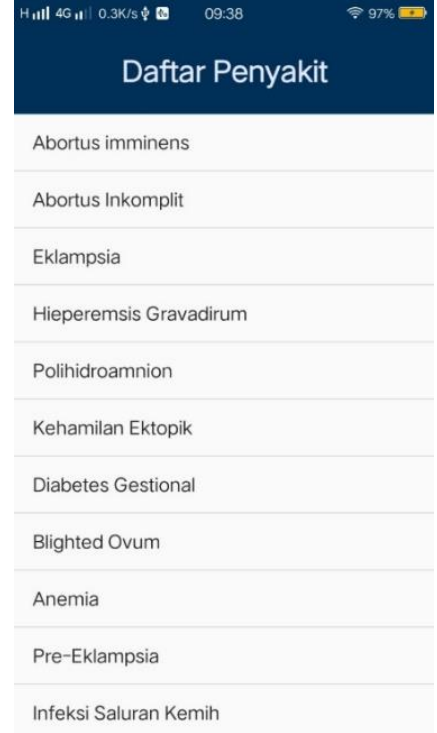

Gambar 10. Screenshot Halaman Daftar Penyakit

5. Halaman Pilih Penyakit

Tampilan halaman pilih penyakit merupakan halaman yang berisikan halaman tentang informasi penyakit yang dipilih pada daftar penyakit.

Blighted Ovum
Deskripsi
Blighted ovum (kehamilan anembrionik atau
kehamilan kosong) adalah kondisi yang muncul ketika
sel telur yang dibuahi menempel di dinding uterus, tapi
tidak berkembang menjadi embrio
Penyebab
Penyebab dari Blighted Ovum sampai saat ini belum
diketahui secara pasti, namun di duga karena
adanya kelainan kromosom pada fetus yang sedang
berkembang. Kelain kromoson bisa dikarenakan
oleh faktor genetik atau bisa juga karena kualitas
sel telur dan sperma yang kurang bagus. Selain itu,
pembelahan sel yang tidak sempurna juga dapat
mengakibatkan Blighted Ovum (BO).
Solusi
Menggunakan obat-obatan seperti misoprostol pada
basis pasien rawat jalan mungkin merupakan pilihan
lain, tapi dengan adanya kemungkinan perdarahan
dan efek samping. Setelah keguguran, dokter
mungkin menyuruh menunggu selama setidaknya 1
sampai 3 siklus menstruasi sebelum mencoba hamil
lagi.

Gambar 11. Screenshot Halaman Pilih Penyakit

6. Halaman Cek Gejala

Tampilan halaman cek gejala merupakan halaman yang berisikan pilihan gejala apa saja yang diderita user.

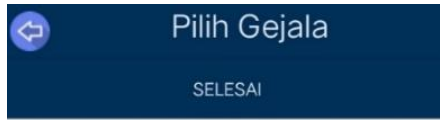

$\square \quad$ Nyeri yang sangat hebat

$\square \quad$ Serviks Tertutup

$\square$ Serviks masih Membuka

$\square \quad$ Pembesaran Uterus sesuai Masa Kehamilan

$\square$ Persalinan Lebih Cepat

$\square \quad$ Adanya protein dalam Air Seni

$\square \quad$ Peningkatan tekanan darah hingga (140/90)

$\square$ Menstruasi lebih berat dari biasanya

$\square \quad$ Vagina Berbintik atau berdarah

$\square \quad$ Terjadi di Tri-Semester Akhir

Gambar 12. Screenshot Halaman Cek Gejala

7. Halaman Hasil Analisa

Tampilan halaman hasil analisa merupakan halaman yang berisikan tentang penyakit hasil dari konsultasi user

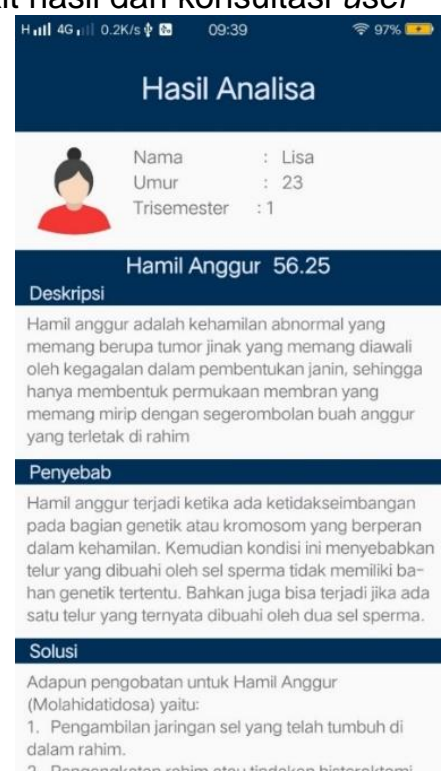

Gambar 13. Screenshot Halaman Hasil Analisa

8. Halaman Keluar

Tampilan halaman keluar merupakan halaman saat user memilih menu keluar untuk keluar dari program. 


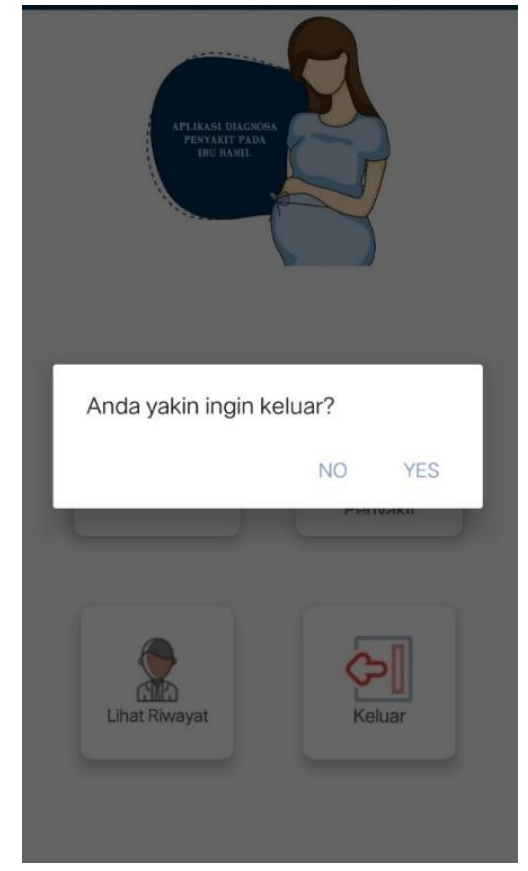

Gambar 14. Screenshot Halaman Keluar

\section{Kesimpulan}

Beberapa kesimpulan dari sistem pakar diagnosa penyakit pada ibu hamil sebagai berikut:

1. Aplikasi sistem pakar ini dapat memberikan pengetahuan mengenai diagnosa penyakit gangguan kehamilan terhadap ibu hamil.

2. Aplikasi sistem pakar ini dapat menjadi media untuk berkonsultasi mengenai penyakit pada masa kehamilan

3. Aplikasi sistem pakar ini dapat membantu mengurangi banyaknya biaya konsultasi ke dokter ahli kandungan.

\section{Referensi}

Dini. (2016). 12 Kelebihan dan Kekurangan OS Android. Retrieved May 9, 2018, from

https://dosenit.com/software/sistemoperasi/kelebihan-dan-kekuranganos-android

Handayani, I. (2017). Angka Kematian Ibu di Indonesia Dinilai Masih Tinggi. Retrieved April 7, 2018, from http://www.beritasatu.com/kesra/4410 92-angka-kematian-ibu-di-indonesiadinilai-masih-tinggi.html
Junianto, E., \& Riana, D. (2017). Penerapan PSO Untuk Seleksi Fitur Pada Klasifikasi Dokumen Berita Menggunakan NBC, 4(1), 38-45.

Kusrini, \& Luthfi, E. taufiq. (2009). Algoritma Data Mining. (T. A. Prabawati, Ed.) (1st ed.). Andi Offset. Retrieved from https://books.google.co.id/books?id=Ojclag7308C\&printsec=frontcover $\#=$ onepage \&q\&f=false

Maryani, R., \& Haryanto, D. (2018). Sistem pakar diagnosa penyakit pada ibu hamil dengan metode forward chaining, 1(1).

Minardi, J., \& Suyatno. (2016). Sistem Pakar Untuk Diagnosa Penyakit Kehamilan Menggunakan Metode Dempster-Shafer Dan Decision Tree, 7(1), 83-98.

Qamaruzzaman, M. H., \& Sam'ani. (2016). Sistem Pakar Untuk Mendiagnosa Penyakit Mata Pada Manusia Menggunakan Teorema Bayes. Indonesian Journal on Networking and Security, 5(4), 7-11.

Rahmayu, M. (2013). Pendeteksian diagnosa penyakit kandungan pada ibu hamil dengan menggunakan metode forward chaining, (1), 227235.

Ramanda, K. (2015). Penerapan sistem pakar untuk mendiagnosa penyakit pada kehamilan, 179-185.

Rosnelly, R. (2012). Sistem Pakar: Konsep dan Teori. (P. Y. Jati, Ed.). Yogyakarta: Penerbit Andi.

Sidauruk, A., \& Pujianto, A. (2017). Sistem Pakar Diagnosa Penyakit Tanaman Kelapa Sawit Menggunakan Teorema Bayes, 18 No. 1, 51-56.

Sugiyono. (2008). Metode Penelitian Kuantitatif Kualitatif dan $R \& D$. Bandung: Alfabeta.

Syahputra, T., Dahria, M., \& Putri, P. D. (2017). Anemia Dengan Menggunakan Metode. 